Case Reports in
Gastroenterology
Case Rep Gastroenterol 2020;14:632-636

DOI: $10.1159 / 000511248$

Published online: November 26, 2020

(C) 2020 The Author(s)

Published by S. Karger AG, Basel www.karger.com/crg

This article is licensed under the Creative Commons Attribution-NonCommercial 4.0 International License (CC BY-NC) (http://www.karger.com/Services/OpenAccessLicense). Usage and distribution for commercial purposes requires written permission.

\title{
Primary Hepatic Lymphoma in a Patient with Chronic Hepatitis B
}

\author{
Soumaya Mrabet ${ }^{a, d}$ Houneida Zaghouani ${ }^{b, d} \quad$ Sarra Mestiri ${ }^{c, d}$ \\ Imen Akkaria, ${ }^{a} \quad$ Elhem Ben Jaziaa, d \\ aDepartment of Gastroenterology, Farhat Hached University Hospital, Sousse, Tunisia; \\ ${ }^{b}$ Department of Radiology, Farhat Hached University Hospital, Sousse, Tunisia; \\ 'Department of Anatomical Pathology, Farhat Hached University Hospital, Sousse, Tunisia; \\ dFaculty of Medicine Ibn El Jazzar, Sousse, Tunisia
}

\author{
Keywords \\ Chemotherapy · Cirrhosis - Lymphoma
}

\begin{abstract}
Primary hepatic lymphoma is a rare disease, accounting for only $0.1 \%$ of malignant liver tumors. The subtype of diffuse large B-cell lymphoma (DLBCL) is more infrequent. In contrast to hepatitis $C$ virus, the association between hepatitis B virus and lymphoma is less clear. Here, we report the case of a 52-year-old patient followed for chronic hepatitis $B$ complicated by cirrhosis, associated with a primary hepatic $D L B C L$, with a good response to chemotherapy.

\section{Introduction}

Lymphomas comprise a heterogeneous group of malignancies that include non-Hodgkin's lymphoma (NHL), Hodgkin's lymphoma, multiple myeloma, acute lymphoblastic lymphoma, and chronic lymphocytic leukemia. NHL is the most prevalent subtype and represents $4.3 \%$ of all new cancer cases [1]. Primary hepatic lymphoma (PHL) is a rare disease, with an incidence of only $0.1 \%$ of malignant liver tumors. The subtype of diffuse large B-cell lymphoma (DLBCL) is more infrequent [2]. Hepatitis $C$ virus has been the most frequently studied hepatitis virus

\section{KARGER}




\section{Case Reports in Gastroenterology}

Case Rep Gastroenterol 2020;14:632-636 DOI: $10.1159 / 000511248$

c) 2020 The Author(s). Published by S. Karger AG, Basel www.karger.com/crg

Mrabet et al.: PHL in a Patient with Chronic Hepatitis B

as a risk factor of lymphoma development. In contrast, the association between hepatitis $B$ virus (HBV) and lymphoma is less clear. In fact, $\mathrm{HBV}$ has been identified as a major risk factor for hepatocellular carcinoma. However, the association between HBV infection and other cancer types such as NHL has not always been clear [3].

\section{Case Report}

A 52-year-old patient followed for viral cirrhosis B treated with entecavir $1 \mathrm{mg}$ for 3 years, was hospitalized for abdominal pain associated with significant weight loss. On physical examination, the patient was in good general condition. There were no palpable peripheral lymphadenopathies or hepatosplenomegaly. The blood count showed white blood cells at 9,900 cells $/ \mathrm{mm}^{3}$, hemoglobin at $12.6 \mathrm{~g} / \mathrm{dL}$, and platelets at 273,000 cells $/ \mathrm{mm}^{3}$. The prothrombin level, the renal function, as well as the hepatic assessment were without anomalies. The lactate dehydrogenase level was normal (106 IU/L). The tumor markers were negative (ACE, CA199, PSA, and alpha-fetoprotein). The viral load of HBV was undetectable.

The thoraco-abdomino-pelvic CT scan had identified 3 hypodense hepatic nodules between 11 and $28 \mathrm{~mm}$ in size, as well as multiple diffuse secondary pulmonary micronodules (Fig. 1). Vascular behavior of liver nodules did not suggest hepatocellular carcinoma. Liver biopsy from a liver nodule showed infiltration of the hepatic parenchyma by lymphoid proliferation with large and medium cells, with atypical nuclei and mitoses (Fig. 2a). The immunohistochemical study showed intense and diffuse expression of CD45 and CD20 by tumor cells (Fig. 2b). The diagnosis of DLBCL was retained. There was no tumor infiltration on osteomedullary biopsy. Based on clinical, laboratory, and pathological examinations, the patient was diagnosed with primary hepatic NHL stage IV. Chemotherapy based on CHOP (cyclophosphamide, doxorubicin, vincristine, and prednisone) scheme associated with rituximab was then initiated in October 2019. The CT scan after the first chemotherapy showed a marked reduction in the size of the liver nodules. These findings suggest that the treatment was satisfactory, and the patient achieved partial remission.

\section{Discussion/Conclusion}

Primary liver non-Hodgkin's lymphoma is extremely rare, accounting for $0.4 \%$ of all primary extranodal lymphoma and $0.016 \%$ of all cases of NHL [2]. PHL may occur at any age but is more common in males aged about 50 years. The male-to-female ratio for the disease incidence is about $3: 1[4]$.

The clinical manifestations of PHL are nonspecific. The most frequent signs are fatigue, loss of appetite, night sweats, fever, and weight loss. Some patients show hepatomegaly, abdominal pain, or liver function abnormalities [2].

DLBCL is one of the most common lymphoid malignancies, accounting for $30-40 \%$ of NHL [5]. It was the histological type found in our patient, followed for viral cirrhosis B.

Although a positive association between HBV and NHL was found in 1994, it has been less studied compared with hepatitis $\mathrm{C}$ virus. HBV has been commonly recognized as a risk factor for hepatocellular carcinoma, even without cirrhosis [6]. Concerning the association of HBV and lymphoma, several cohort studies have reported controversial results relating to this association [1]. In Asian and European countries where HBV has moderate or moderate-high prevalence, the association was more significant than that in Oceania and American countries 


\section{Case Reports in Gastroenterology}

\begin{tabular}{l|l}
\hline Case Rep Gastroenterol 2020;14:632-636 \\
\hline DOI: 10.1159/000511248 & $\begin{array}{l}\text { ○ 2020 The Author(s). Published by S. Karger AG, Basel } \\
\text { www.karger.com/crg }\end{array}$ \\
\hline
\end{tabular}

Mrabet et al.: PHL in a Patient with Chronic Hepatitis B

where HBV has low prevalence. In a meta-analysis including 58 studies with a total of 53,714 NHL cases and 1,778,591 controls, the authors have demonstrated a significantly increased NHL risk in HBV-infected individuals with an odds ratio of 2.5 [7].

Furthermore, a nationwide population-based HBV cohort group with a non-HBV control group, including 203,031 in each cohort with a mean follow up of 7-9 years, chronic hepatitis $B$ infection was found to be associated with an increased risk of lymphoma, particularly with DLBCL [1]. However, another nationwide cohort study that included 4,345 patients with chronic hepatitis B and 26,070 controls found no positive association between chronic hepatitis B and NHL [8].

The pathogenic role of HBV infection in lymphoma remains undetermined. Marcucci's group proposed two possible pathogenic roles of HBV in lymphomagenesis: the first is the direct infection of HBV in lymphocytes with HBV nucleic acid sequences integrated in the host genome, leading to overexpression of oncogenes or downregulation of tumor suppressor genes, and the second relates to chronic antigen stimulation [1]. Our patient developed PHL despite being treated with antiviral therapy with an undetectable plasma viral load. This can be explained by the fact that an advanced fibrosis is already installed but also by the presence of the viral genome in the hepatocytes.

PHL is a chemosensitive tumor with a complete remission rate of $85 \%$ through chemotherapy and an event-free 5-year survival of 70\%. The chemotherapy regimen is mainly based on CHOP [2]. However, it also has been reported that DLBCL patients infected with HBV are diagnosed at a young age with a more advanced disease stage and show a significantly worse outcome [5]. In our case, the patient had a partial remission after chemotherapy based on CHOP combined with rituximab.

In conclusion, PHL is an extremely rare condition in clinical practice. Moreover, DLBCL is rarely reported worldwide. We have reported this observation in view of the rarity of PHL associated with chronic hepatitis B complicated by cirrhosis. The mechanism explaining this association is still unclear. Our observation may suggest the need to consider cancer surveillance, other than hepatocellular carcinoma, in HBV-infected subjects.

\section{Statement of Ethics}

We obtained written informed consent of the patient for the publication of this case including images. Research was conducted ethically in accordance with the World Medical Association Declaration of Helsinki.

\section{Conflict of Interest Statement}

The authors have no conflicts of interest to declare.

\section{Funding Sources}

No funding sources. 


\section{Case Reports in Gastroenterology}

\section{Author Contributions}

Soumaya Mrabet and Houneida Zaghouani: Collecting data and writing the manuscript. Sarra Mestiri, Imen Akkari, and Elhem Ben Jazia: literature review.

\section{References}

1 Su TH, Liu CJ, Tseng TC, Chou SW, Liu CH, Yang HC, et al. Chronic hepatitis B is associated with an increased risk of B-cell non-Hodgkin's lymphoma and multiple myeloma. Aliment Pharmacol Ther. 2019 Mar;49(5):589-98.

2 Liu Y, Jiang J, Wu Q, Zhang Q, Xu Y, Qu Z, et al. A Case of Primary Hepatic Lymphoma and Related Literature Review. Case Reports Hepatol. 2016;2016:6764121.

3 Becker N, Schnitzler P, Boffetta P, Brennan P, Foretova L, Maynadié M, et al. Hepatitis B virus infection and risk of lymphoma: results of a serological analysis within the European case-control study Epilymph. J Cancer Res Clin Oncol. 2012 Dec;138(12):1993-2001.

4 Gatselis NK, Dalekos GN. Education and imaging. Hepatobiliary and pancreatic: primary hepatic lymphoma. J Gastroenterol Hepatol. 2011 Jan;26(1):210-210.

5 Ren W, Ye X, Su H, Li W, Liu D, Pirmoradian M, et al. Genetic landscape of hepatitis B virus-associated diffuse large B-cell lymphoma. Blood. 2018 Jun;131(24):2670-81.

6 Song C, Lv J, Liu Y, Chen JG, Ge Z, Zhu J, et al.; China Kadoorie Biobank Collaborative Group. Associations Between Hepatitis B Virus Infection and Risk of All Cancer Types. JAMA Netw Open. 2019 Jun;2(6):e195718195718.

7 Li M, Gan Y, Fan C, Yuan H, Zhang X, Shen Y, et al. Hepatitis B virus and risk of non-Hodgkin lymphoma: an updated meta-analysis of 58 studies. J Viral Hepat. 2018 Aug;25(8):894-903.

8 Andersen ES, Omland LH, Jepsen P, Krarup H, Christensen PB, Obel N, et al.; DANVIR Cohort Study. Risk of all-type cancer, hepatocellular carcinoma, non-Hodgkin lymphoma and pancreatic cancer in patients infected with hepatitis B virus. J Viral Hepat. 2015 Oct;22(10):828-34.

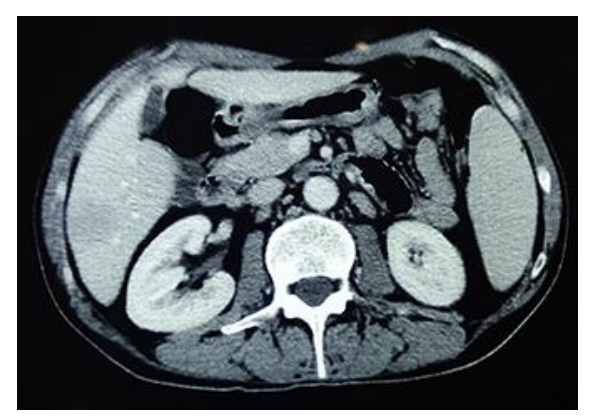

Fig. 1. The thoraco-abdomino-pelvic CT scan had identified 3 hypodense hepatic nodules between 11 and $28 \mathrm{~mm}$ in size. 
Case Reports in Gastroenterology
Case Rep Gastroenterol 2020;14:632-636

DOI: $10.1159 / 000511248$

(c) 2020 The Author(s). Published by S. Karger AG, Basel www.karger.com/crg

Mrabet et al.: PHL in a Patient with Chronic Hepatitis B
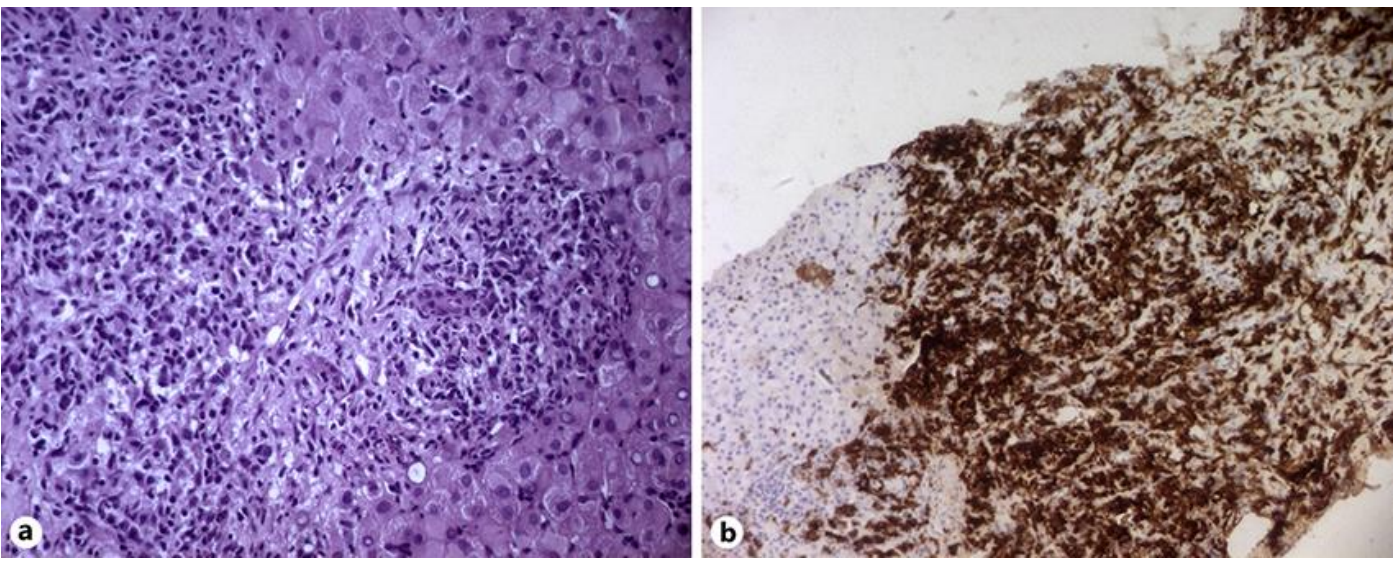

Fig. 2. a Liver biopsy from a liver nodule showed infiltration of the hepatic parenchyma by lymphoid proliferation with large and medium cells, with atypical nuclei and mitoses. HE. $\times 200$. b The immunohistochemical study showed intense and diffuse expression of CD45 and CD20 by tumor cells. HC. $\times 200$. 